\title{
The Impact of Entrepreneurship on Economic Growth
}

Citation for published version (APA):

Carree, M. A., \& Thurik, A. R. (2003). The Impact of Entrepreneurship on Economic Growth. In Audretsch, \& Acs (Eds.), Handbook of Entrepreneurship Research (pp. 437-471). Kluwer Academic Publishers. https://doi.org/10.1007/0-387-24519-7_17

Document status and date:

Published: 01/01/2003

DOI:

10.1007/0-387-24519-7_17

Document Version:

Publisher's PDF, also known as Version of record

\section{Please check the document version of this publication:}

- A submitted manuscript is the version of the article upon submission and before peer-review. There can be important differences between the submitted version and the official published version of record.

People interested in the research are advised to contact the author for the final version of the publication, or visit the DOI to the publisher's website.

- The final author version and the galley proof are versions of the publication after peer review.

- The final published version features the final layout of the paper including the volume, issue and page numbers.

Link to publication

\footnotetext{
General rights rights.

- You may freely distribute the URL identifying the publication in the public portal. please follow below link for the End User Agreement:

www.umlib.nl/taverne-license

Take down policy

If you believe that this document breaches copyright please contact us at:

repository@maastrichtuniversity.nl

providing details and we will investigate your claim.
}

Copyright and moral rights for the publications made accessible in the public portal are retained by the authors and/or other copyright owners and it is a condition of accessing publications that users recognise and abide by the legal requirements associated with these

- Users may download and print one copy of any publication from the public portal for the purpose of private study or research.

- You may not further distribute the material or use it for any profit-making activity or commercial gain

If the publication is distributed under the terms of Article $25 \mathrm{fa}$ of the Dutch Copyright Act, indicated by the "Taverne" license above, 


\author{
MARTIN A. CARREE ${ }^{1,2,3}$ and A. ROY THURIK ${ }^{1,2}$ \\ ${ }^{1}$ Centre for Advanced Small Business Economics (CASBEC) at Erasmus University, Rotterdam, \\ ${ }^{2}$ EIM Business and Policy Research, Zoetermeer, \\ ${ }^{3}$ Faculty of Economics and Business Administration, University of Maastricht
}

\title{
17. The Impact of Entrepreneurship on Economic Growth
}

\section{INTRODUCTION}

The last two decades have witnessed a wealth of studies analyzing the determinants of entrepreneurship. While some of these studies are theoretical (e.g. Holmes and Schmitz, 1990), others are empirical (e.g. Evans and Leighton, 1990). The consequences of entrepreneurship, in terms of economic performance, have also generated an extensive literature. However, this literature has generally been restricted to two units of observations - that of the establishment or firm, and that of the region. Noticeably absent are studies linking the impact of entrepreneurship on performance for the unit of observation of the country. A large literature has emerged analyzing the impact of entrepreneurship on economic performance at the level of the firm or establishment. These studies typically measure economic performance in terms of firm growth and survival (Audretsch, 1995; Caves, 1998; Sutton, 1997).

The compelling stylized facts that have emerged from this literature are that entrepreneurial activity, measured in terms of firm size and age, is positively related to growth. ${ }^{1}$ New firms and (very) small firms grow systematically larger than large and established incumbents. These findings hold across modern Western economies and across time periods. The link between entrepreneurship and performance has also been extended beyond the unit of observation of the firm to include geographic regions. A small literature exists linking measures of entrepreneurial activity for regions to the economic performance of those regions (e.g. Audretsch and Fritsch, 2002; Acs and Armington, 2003).

However, when it comes to linking entrepreneurship to growth at the national level, there is a relative void despite recent efforts of the Global Entrepreneurship Monitor (GEM) research program (Reynolds et al., 2001). The purpose of this chapter is to provide a survey of what is known about the links between entrepreneurial activity and macro-economic growth. Despite

\footnotetext{
${ }^{1}$ See Audretsch, Klomp and Thurik (2002) for a recent survey of studies dealing with Gibrat's Law.
} 
the numerous studies claiming a link of entrepreneurship to economic growth the relative void may be attributable to a paucity of theoretical frameworks linking entrepreneurship to growth, as well as severe constraints in measuring entrepreneurship in a cross-national context. Furthermore, there is the reversed causality of economic development influencing entrepreneurial activities. In this chapter we provide five short overviews of the relevant literature and complement them with some new material.

Explanations for economic growth have generally been restricted to the realm of macro-economics (Romer, 1990). However, a different scholarly tradition linking grow th to industrial organization dates back at least to Schumpeter (1934). According to this tradition, performance, measured in terms of economic growth, is shaped by the degree to which the industry structure utilizes scarce resources most efficiently. This (most efficient) industrial structure does not alter in case its underlying determinants are stable. However, as Chandler (1990), Scherer and Ross (1990) and Dosi (1988) emphasize, a change in the underlying determinants would be expected to result in a change in the industry structure most conducive to growth. Certainly, Chandler (1990) and Scherer and Ross (1990) identified a shift in industry structure towards increased centralization and concentration throughout the first two-thirds of the previous century as a result of changes in the underlying technology along with other factors.

More recently, a series of studies has identified a change in the determinants underlying the industry structure that has reversed this trend. The most salient point of this change is that technological change, globalization, deregulation, shifts in the labor supply, variety in demand, and the resulting higher levels of uncertainty have rendered a shift in the industry structure away from greater concentration and centralization towards less concentration and decentralization. A series of empirical studies have uncovered two systematic findings regarding the response of industry structure to changes in the underlying determinants. The first is that the industry structure is generally shifting towards an increased role for small firms. The second is that the extent and timing of this shift is anything but identical across countries. Apparently, institutions and policies in certain countries have facilitated a greater and more rapid response to technological change and globalization, along with the other underlying factors, by shifting to a less centralized and more dispersed industry structure than has been the case in other countries. The question of whether countries that have shifted towards a greater role for entrepreneurship enjoy stronger growth is of large importance to policy makers.

Entrepreneurship is "at the heart of national advantage" (Porter, 1990, p. 125). Concerning the role of entrepreneurship in stimulating economic growth, many links have been discussed. It is of eminent importance for carrying out innovations and for enhancing rivalry. This directs our attention to two related phenomena of the 1980 s and 1990s: The resurgence of small business and the revival of entrepreneurship. There is ample evidence that economic activity moved away from large firms to small firms in the 1970s and 1980s. 
The most impressive and also the most cited is the share of the 500 largest American firms, the so-called Fortune 500. Their employment share dropped from 20 percent in 1970 to 8.5 percent in 1996 (Carlsson, 1992, 1999).

Acs and Audretsch (1993) and Carlsson (1992) provide evidence concerning manufacturing industries in countries in varying stages of economic development. Carlsson advances two explanations for the shift toward smallness. The first deals with fundamental changes in the world economy from the 1970s onwards. These changes relate to the intensification of global competition, the increase in the degree of uncertainty and the growth in market fragmentation. The second deals with changes in the character of technological progress. $\mathrm{He}$ shows that flexible automation has various effects resulting in a shift from large to smaller firms. Also Piore and Sabel (1984) argue that the instability of markets in the 1970s resulted in the demise of mass production and promoted flexible specialization. This fundamental change in the path of technological development led to the occurrence of vast diseconomies of scale.

Brock and Evans (1989) argue that the shift away from large firms is not confined to manufacturing industries and provide four more reasons why this shift has occurred: The increase of labor supply leading to lower real wages and coinciding with an increasing level of education; changes in consumer tastes; relaxation of (entry) regulations and the fact that we are in a period of creative destruction. Loveman and Sengenberger (1991) stress the influence of two trends of industrial restructuring: That of decentralization and vertical disintegration and that of the formation of new business communities. These intermediate forms of market coordination flourish owing to declining costs of transaction. Furthermore, they emphasize the role of public and private policies promoting the small business sector. Audretsch and Thurik (2000) point at the necessary shift towards the knowledge-based economy being the driving force behind the move from large to smaller businesses. In their view globalization and technological advancements are the major determinants of this challenge of the Western countries.

The causes of this shift are one aspect. Its consequences cover a different area of research. Acs (1992) was among the first to discuss them. He distinguishes four consequences of the increased importance of small firms: Entrepreneurship, routes of innovation, industry dynamics and job generation. His claims are that small firms play an important role in the economy serving as agents of change by their entrepreneurial activity, being the source of considerable innovative activity, stimulating industry evolution and creating an important share of the newly generated jobs. Acs and Audretsch (1990) and Audretsch (1995) are key references on the role of smaliness in the process of innovative activities. See also Cohen and Klepper (1992) discussing the role of firm size and diversity for obtaining technological progress. The role of small firms in the job creation process remains controversial. ${ }^{2}$

\footnotetext{
${ }^{2}$ See Carree and Klomp (1996) and Davis, Haltiwanger and Schuh (1996) for a discussion.
} 
The reevaluation of the role of small firms is related to a renewed attention to the role of entrepreneurship in firms. In case the size class distribution has an influence on growth, it must be differences in organization that matter. The major difference between the organization of a large firm and a small one is the role of ownership and management. In a small firm usually there is one person or a very small group of persons, who are in control and who shapes the firm and its future. The role of such a person is often described with the term "entrepreneurship". Also, attention has been given to the role of entrepreneurship in economic development, i.e., for the functioning of markets. Many economists and politicians now have an intuition that there is a positive impact of entrepreneurship on the growth of GDP and employment. Furthermore, many stress the role of the entrepreneur in implementing innovations. This renewed interest of politicians and economists coincides with a revival of business ownership rates in most Western economies.

In the remainder of this introductory section some remarks will be made about conceptualizing entrepreneurship. In section 2 we will deal with the influence of economic development on entrepreneurship. In section 3 types of entrepreneurship and their relation to economic growth are discussed. The effect of the choice between entrepreneurship and employment is dealt with in section 4. Sections 5 and 6 deal with entrepreneurship in endogenous growth models and with empirical evidence, respectively. Section 7 concludes. The general emphasis will be on the role of entrepreneurship for economic development at the macro-economic level. Sections 3,4 and 5 contain some new material. Readers not interested in the sometimes rigorous approach of the economic sciences can skip the mathematical expositions of these sections.

\section{Conceptualizing Entrepreneurship}

Entrepreneurship is an ill-defined, multidimensional, concept. The difficulties in defining and measuring the extent of entrepreneurial activities complicate the measurement of their impact on economic performance. Understanding their role in the process of growth requires a framework because there are various intermediate variables or linkages to explain how entrepreneurship influences economic growth. Examples of these intermediate variables are innovation, variety of supply, entry and exit of firms (competition), specific efforts and energy of entrepreneurs, etc. See Figure 1 where also some conditions for entrepreneurship are provided. These conditions include personal traits that lie at the origin of entrepreneurship and cultural and institutional elements. ${ }^{3}$

Entrepreneurship has to do with activities of individual persons. The concept of economic growth is relevant at levels of firms, regions, industries and nations. Hence, linking entrepreneurship to economic growth means linking the individual level to aggregate levels. In order to consider this link we first pay attention

\footnotetext{
${ }^{3}$ See also Audretsch, Verheul, Thurik and Wennekers (2002) and Wennekers, Uhlaner and Thurik (2002).
} 


\begin{tabular}{c} 
Conditions (personal, cultural, institutional) \\
$\downarrow$ \\
Entrepreneurship (multidimensional) \\
$\downarrow$ \\
Intermediate linkages (innovation, variety, competition, entrepreneurial efforts, etc) \\
$\downarrow$ \\
Economic growth \\
\hline
\end{tabular}

Figure 1. Introductory framework

Source: Wennekers and Thurik (1999).

to a definition of "entrepreneurship". Inspired by Hébert and Link (1989), Bull and Willard (1993) and Lumpkin and Dess (1996), the following definition of entrepreneurship can be proposed: Entrepreneurship is the manifest ability and willingness of individuals, on their own, in teams, within and outside existing organizations to perceive and create new economic opportunities (new products, new production methods, new organizational schemes and new product-market combinations), and to introduce their ideas in the market, in the face of uncertainty and other obstacles, by making decisions on location, form and the use of resources and institutions (Wennekers and Thurik, 1999). Essentially, entrepreneurship is a behavioral characteristic of persons. It should be noted that entrepreneurship is not an occupation and that entrepreneurs are not a well-defined occupational class of persons. Even obvious entrepreneurs may exhibit their entrepreneurship only during a certain phase of their career and/or concerning a certain part of their activities. ${ }^{4}$

Entrepreneurship is not synonymous with small business. Certainly, small firms are an outstanding vehicle for individuals to channel their entrepreneurial ambitions. The small firm is an extension of the individual in charge (Lumpkin and Dess, 1996, p. 138). However, entrepreneurship is not restricted to persons starting or operating an (innovative) small firm. Enterprising individuals in large firms, the so-called "intrapreneurs" or "corporate entrepreneurs", undertake entrepreneurial actions as well. In these environments there is a tendency of "mimicking smallness," for instance using business units, subsidiaries or joint ventures.

Because in colloquial speech many terms like entrepreneurs, self-employed and businessmen are used indiscriminately, its operationalization and measurement are far from obvious. However, one can make some pragmatic distinctions. First, between the concepts entrepreneurial, and managerial in the sense of

\footnotetext{
${ }^{4}$ See also Gartner (1989, p. 64) who asserts that "The entrepreneur is not a fixed state of existence, rather entrepreneurship is a role that individuals undertake to create organizations"; and Schumpeter (1934, p. 78) who states that "Because being an entrepreneur is not a profession and as a rule not a lasting condition, entrepreneurs do not form a social class in the technical sense as, for example, landowners or capitalists or workmen do."
} 
organizing and coordinating. Second, between business-owners or self-employed (including owner-managers of incorporated firms) ${ }^{5}$ and employees. Based on this double dichotomy of self-employed versus employee and entrepreneurial versus managerial, three types of entrepreneurs may be distinguished. These three types are the Schumpeterian entrepreneurs, the intrapreneurs and the managerial business owners who are entrepreneurs in a formal sense only. This is illustrated in Table 1.

Schumpeterian entrepreneurs are found mostly in small firms. They own and direct independent firms that are innovative and creatively destroy existing market structures. After realizing their goals Schumpeterians often develop into managerial business owners, but some may again start new ventures. Intrapreneurs or entrepreneurial managers also belong to the core of entrepreneurship. By taking commercial initiatives on behalf of their employer, and by risking their time, reputation and sometimes their job in doing so, they are the embodiment of leadership resulting in entrepreneurial ventures in larger firms. Sometimes these entrepreneurial employees, either in teams or on their own, spin off, start new enterprises and become Schumpeterian entrepreneurs. Managerial business owners (entrepreneurs in a formal sense) are to be found in the large majority of small firms. They include many franchisees, shopkeepers and people in professional occupations. They belong to what Kirchhoff (1994) calls 'the economic core' and are the seedbed for some of the entrepreneurial ventures.

\section{The INFLuence of ECONOMIC DEVELOPMENT ON ENTREPRENEURShIP}

The relationship between unemployment and entrepreneurship has been shrouded with ambiguity. On the one hand, one strand in the literature has found that unemployment stimulates entrepreneurial activity, which has been termed as a "refugee effect." On the other hand, a very different strand in the literature has identified that higher levels of entrepreneurship reduce unemployment, or what has been termed as a "Schumpeter effect." Taken together, these two relationships result in considerable ambiguities about the relationship between rates of unemployment and self-employment (Audretsch, Carree and Thurik, 2001). Similarly, there exist ambiguities about the interrelationship of

Table 1. Three types of entrepreneurs

\begin{tabular}{lll}
\hline & Self-employed & Employees \\
\hline Entreprencurial & Schumpeterian entrepreneurs & Intrapreneurs \\
Managerial & Managerial business owners & Executive managers \\
\hline
\end{tabular}

Source: Wennekers and Thurik (1999).

\footnotetext{
${ }^{5}$ The terms self-employed and business owners will be used interchangeably throughout this chapter.
} 
entrepreneurship and economic growth. In this section we will discuss how business ownership rates are influenced by economic development. We will pay attention to the role the "Schumpeterian regime switch" has played in this relationship. We discuss the pre-1970s era of declining business ownership rates and the period thereafter in which the rates have risen in most Western economies. The emphasis of the succeeding sections will be on how the business ownership rate at the economy-wide level influences the extent of structural transformation and subsequent economic growth.

Joseph Schumpeter's contribution to our understanding of the mechanisms of technological progress and economic development is widely recognized. In The Theory of Economic Development he emphasizes the role of the entrepreneur as prime cause of economic development. He describes how the innovating entrepreneur challenges incumbent firms by introducing new inventions that make current technologies and products obsolete. This process of creative destruction is the main characteristic of what has been called the Schumpeter Mark I regime. In Capitalism, Socialism and Democracy, Schumpeter focuses on innovative activities by large and established firms. He describes how large firms outperform their smaller counterparts in the innovation and appropriation process through a strong positive feedback loop from innovation to increased $R \& D$ activities. This process of creative accumulation is the main characteristic of the Schumpeter Mark II regime.

The extent to which either of the two Schumpeterian technological regimes prevails in a certain period and industry varies. It may depend upon the nature of knowledge required to innovate, the opportunities of appropriability, the degree of scale (dis)economies, the institutional environment, the importance of absorptive capacity, demand variety, etc. Industries in a Schumpeter Mark II regime are likely to develop a more concentrated market structure in contrast to industries in a Schumpeter Mark I regime where small firms will proliferate.

\section{Decline of Business Ownership}

The first three-quarters of the 20th century can be described as a period of accumulation. From the Second Industrial Revolution till the 1970s the large firm share has risen in most industries and the economy as a whole. It was the period of "scale and scope" (Chandler, 1990). It was the era of the hierarchical industrial firm growing progressively larger by exploiting economies of scale and scope in areas like production, distribution, marketing and R\&D. The conglomerate merger wave of the late 1960 s seemed to have set the case. The period has the characteristics of the Schumpeter Mark II regime with a declining small firm presence in most industries. The policies of (European) governments also contributed to this decline by promoting large business. The proportion of the labor force that is self-employed has decreased in most Western countries until the mid-1970s. Several authors (Blau, 1987; Kuznets, 1971; Schultz, 1990; Yamada, 1996) have reported a negative relationship between economic devel- 
opment and the business ownership (self-employment) rate. ${ }^{6}$ In many Western countries and industries this decline has ended and even reversed. Many old and large firms have been losing ground to their small, new and more entrepreneurial counterparts. We label this as a regime switch (reversal of the trend) from Schumpeter Mark II to Schumpeter Mark I. Audretsch and Thurik (2001a) label this as a regime switch from a managed to an entrepreneurial economy.

\section{Reversal of the Trend}

Since the mid-1970s the self-employment rate has started to rise again in most modern economies. Blau (1987) observes that, while the proportion of selfemployed in the nonagricultural U.S. labor force declined during most of this century, this decline bottomed out in the early 1970s and started to rise until at least $1982 .^{7}$ More recently business ownership increased in several other countries as well. Audretsch and Thurik (2001a) show that the business ownership growth rate was higher in the period of 1998-1986 than in the period 1986-1974 for 16 of 23 OECD countries. Also other authors have provided evidence of a reversal of the trend towards less self-employment. Acs, Audretsch and Evans (1994) report that of 23 OECD-countries, 15 experienced an increase in the self-employment rate during the 1970s and 1980s. They show that the weighted average of the self-employment rate in OECD-countries rose slightly from $8.4 \%$ in 1978 to $8.9 \%$ in 1987. Audretsch and Thurik (2001a) show that this growth accelerates in the 1990s. Large firms have been downsizing and restructuring in order to concentrate on "core business" again. In the meantime the entrepreneur has risen from the dead. High-technology innovative small firms have come at the forefront of technological development in many (new) industries.

There are several well-documented reasons for the revival of small business and self-employment in Western economies. ${ }^{8}$ First, the last 25 years of the 20 th century may be seen as a period of creative destruction. Piore and Sabel (1984) use the term "Industrial Divide", Jensen (1993) prefers the term "Third Industrial Revolution", and Freeman and Perez (1988) interpret it as the

\footnotetext{
${ }^{6}$ There are a couple of theoretical models proposed to explain the decline of self-employment, and of small business presence in general. Lucas (1978) shows how rising real wages may raise the opportunity cost of self-cmployment relative to the return. Given an underlying "managerial" talent distribution this induces marginal entrepreneurs (in this context Lucas refers to managers) to become employees. This pushes up the average size of firms. Iyigun and Owen (1998) develop a model implying that economic development is associated with a decline in the number of entrepreneurs relative to the total number of employees. They argue that fewer individuals are willing to run the risk associated with becoming an entrepreneur as the "safe" professional earnings rise with economic development. See also Schaffner (1993).

${ }^{7}$ Other sources showing that the growing importance of large business has come to a hath in Western countries are Carlsson (1989), Loveman and Sengenberger (1991), Acs and Audretsch (1993), Acs (1996) and Thurik (1999).

${ }^{8}$ Brock and Evans (1986) were the first to provide an elaborate overview.
} 
transition from the fourth to the fifth Kondratiev wave. The most obvious evidence is the emergence of new industries like the software and biotechnology industries. Small firms play an important role in these new industries. Acs and Audretsch (1987) provide empirical evidence that small firms have a relative innovative advantage over their larger counterparts in such highly innovative industries. Evidence for the comparative advantage of small firms in inventing radically new products is also given in Prusa and Schmitz (1991) and Rothwell (1983, 1984).

Second, new technologies have reduced the importance of scale economies in many sectors. Small technology-based firms started to challenge large companies that still had every confidence in mass production techniques (Meredith, 1987; Carlsson, 1989). Jensen argues that "It is far less valuable for people to be in the same geographical location to work together effectively, and this is encouraging smaller, more efficient, entrepreneurial organizing units that cooperate through technology" (Jensen, 1993, p. 842). This is supported by Jovanovic claiming that: "recent advances in information technology have made market-based coordination cheaper relative to internal coordination and have partially caused the recent decline in firm size and diversification" (Jovanovic, 1993, p. 221).

Third, deregulation and privatization movements have swept the world. In many Western countries there have been strong tendencies to deregulate and privatize (OECD, 1995, pp. 39-49). Phillips (1985) reports that small firms have been dominant in the creation of new businesses and new jobs in deregulated industry sectors in the U.S. in the early 1980s. ${ }^{9}$ In addition, governments acknowledge and promote the role of small (start-up) firms in establishing economic growth and development (OECD, 1998).

Fourth, there has been a tendency of large firms to concentrate on their "core competences" (Carlsson, 1989). Jovanovic (1993) reports that, as a consequence, the 1980 s were characterized by corporate spin-offs and divestment. Aiginger and Tichy (1991) blame the opportunistic conglomerate merger wave of the late 1960s for much of the "back-to-basics" and downsizing (or rightsizing) tendencies.

Fifth, increasing incomes and wealth have led to an increase in the demand for variety (Jackson, 1984). Cross-cultural influences have also enlarged the demand for variety. Small firms are often the most obvious suppliers of new and specialized products. The decrease in diversification as reported by Jovanovic (1993) suggests that large firms have not been capable of entering into such market niches.

Sixth, self-employment is more highly valued as an occupational choice than before. Roughly one out of four young U.S. workers pursue self-employment according to Schiller and Crewson (1997). Kirchhoff (1996) argues that self-

\footnotetext{
${ }^{9}$ See Berkowitz and Holland (2001) for the eflects of privatization on small enterprise formation in Russia.
} 
employment is not characterized anymore as under-employment or as momand-pop establishments, but as a way to achieve a variety of personal goals.

Finally, the employment share of the services sector has been well documented to increase with per capita income (Inman, 1985). Given the relatively small average firm size of most services (barring airlines, shipping and some business and financial services) this creates additional opportunities for business ownership.

Obviously, some of these factors may have a temporary effect only. For example, it is not unlikely for the outsourcing and deregulation waves to dry up. In addition, many of the start-ups in the newly emerged industries fail to survive (for instance, Internet-based start-ups from the late 1990s). On the other hand, there are more permanent effects like the impact of new technologies. We refer again to Freeman and Perez (1988). They claim that in the new techno-economic paradigm (fifth Kondratiev wave) the organization of firms will be "networks" of large and small firms. Moreover, the introduction of these new technologies is also positively related to the stage of economic development because they cannot be made effective without the necessary skills and other investments. This structural influence of economic development is reinforced by the increasing variety of demand for specialized goods and services and the enhanced valuation of self-realization, both dependent on the level of prosperity.

\section{TYPES OF ENTREPRENEURSHIP AND THEIR RELATION TO ECONOMIC Growth}

Throughout intellectual history, the entrepreneur has worn many faces and fulfilled many roles (Hébert and Link, 1989). In this section we focus on three entrepreneurial roles, emphasized by Schumpeter, Kirzner and Knight, respectively. A first is the role of innovator. Schumpeter was the economist who has most prominently drawn attention to the "innovating entrepreneur". ${ }^{10} \mathrm{He}$ or she carries out "new combinations we call enterprise; the individuals whose function it is to carry them out we call entrepreneurs" (Schumpeter, 1934, p. 74). A second is the role of perceiving profit opportunities. We label this role as Kirznerian (or neo-Austrian) entrepreneurship (see for instance Kirzner, 1997). A third is the role of assuming the risk associated with uncertainty. We label this role as Knightian entrepreneurship. ${ }^{11}$ When an individual introduces a new product or starts a new firm, this can be interpreted as an entrepreneurial act in terms of each of the three types of entrepreneurship. The individual is an innovator, he (assumes that he) has perceived a hitherto unnoticed profit

\footnotetext{
${ }^{10}$ Schumpeter's Theory of Economic Development was published in German in 1911, and in English in 1934.

${ }^{11}$ The Knightian entrepreneur has also been interpreted as the "neo-classical entrepreneur" (see for instance Shane, 2000). In the neo-classical (equilibrium) framework, entrepreneurship is explained by fundamental attributes of people (like "taste" for uncertainty).
} 
opportunity and he takes the risk that the product or venture may turn out to be a failure.

Based on their study of the history of economic thought about entrepreneurship, Hébert and Link (1989, p. 47) propose the following "synthetic" definition of who an entrepreneur is and what he does: "the entrepreneur is someone who specializes in taking responsibility for and making judgemental decisions that affect the location, form, and the use of goods, resources, or institutions". When searching for links between entrepreneurship and growth, this definition does not suffice. The dynamics of perceiving and creating new economic opportunities and the competitive dimensions of entrepreneurship need more attention. The key contribution of entrepreneurship to economic growth might be singled out as being "newness". This includes the start-up of new firms but also the transformation of "inventions and ideas into economically viable entities, whether or not, in the course of doing so they create or operate a firm" (Baumol, 1993, p. 198).

The management literature has a broad view upon entry. In surveying this literature, Lumpkin and Dess (1996) integrate the renewing aspects of entrepreneurship. "New entry can be accomplished by entering new or established markets with new or existing goods or services. New entry is the act of launching a new venture, either by a start-up firm, through an existing firm or via internal corporate venturing" (Lumpkin and Dess, 1996, p. 136). In their view, the essential act of entrepreneurship is more than new entry as we see it. Entrepreneurial activities, "new entry" in existing, large firms often takes place by mimicking smallness. Newness through start-ups and innovations as well as competition are the most relevant factors linking entrepreneurship to economic growth. While managerial business owners fulfill many useful functions in the economy such as the organization and coordination of production and distribution, they cannot be viewed as the engine of innovation and creative destruction. This is the major function of Schumpeterian entrepreneurs and intrapreneurs.

\section{Different Types of Entrepreneurship}

In the following model we give an example of the economic impact of (the lack) of Kirznerian (neo-Austrian) and Knightian entrepreneurship (for the latter see also Kihlstrom and Laffont, 1979) using the example of the retail sector. A more Schumpeterian approach will be dealt with in section 5 . The model is a simplified version of the carrying capacity model by Carree and Thurik (1999b). The model is used to indicate how a lack of entrepreneurship may affect economic performance. The non-mathematically interested reader may want to proceed with the last paragraph of this section.

Assume that there are two local markets, labeled $i$ and $j$, in which retailers sell a homogeneous good. Retailers can only be in one market or the other. The total demand by consumers in the two local markets is assumed to have 
price elasticity equal to unity:

$$
Q_{x}=a_{x} / p_{x} \quad x \in\{i, j\} .
$$

Each retailer $k$ in market $x$ maximizes profit $\pi_{k}=\left(p_{x}-\beta\right) q_{k}-\alpha$ where $\alpha$ are fixed costs and $\beta$ are variable costs, both of which are identical across firms. Assume that the retailers form a Cournot oligopoly, hence not taking into account the reactions by competitors when changing the level of output $q_{k}$. Because the cost function of each retailer is assumed to be identical, also the output levels are identical to $q_{k}+Q_{x} / N_{x}$. In case there are $N_{x}$ firms in market $x$, the equilibrium market price is easily derived to be

$$
p_{x}=\beta \frac{N_{x}}{N_{x}-1} \quad x \in\{i, j\} .
$$

Hence, in Cournot equilibrium total output within market $x$ equals

$$
Q_{x}=\frac{a_{x}}{\beta} \frac{N_{x}-1}{N_{x}} .
$$

By inserting equation (3) into the profit function we derive that in equilibrium

$$
\pi_{k}=\frac{\beta Q_{x}}{N_{x}\left(N_{x}-1\right)}-\alpha=\frac{a_{x}}{N_{x}^{2}}-\alpha .
$$

There is an equilibrium across regions in case entrepreneurs in one region earn as much as entrepreneurs in the other region. This implies that

$$
\frac{N_{i}}{N_{j}}=\sqrt{\frac{a_{i}}{a_{j}}}
$$

This equilibrium condition assures maximum total output for the two markets combined given a certain fixed number of entrepreneurs, $N$. To derive this, note that $N_{j}=N-N_{i}$ and that, therefore, the sum of outputs is

$$
Q_{i}+Q_{i}=\left(a_{i} \frac{N_{i}-1}{N_{i}}+a_{j} \frac{N-N_{i}-1}{N-N_{i}}\right) / \beta
$$

Maximizing equation (6) with respect to $N_{i}$ gives us the exact same outcome as given in equation (5). Now we come to the final issue of how many entrepreneurs there will be. Following Carree and Thurik (1999b), we assume there exists a critical profit level $\pi^{*}$ that entrepreneurs seek to receive as compensation for their efforts. In case profit falls short of the critical level, entrepreneurs will exit until the profit level increases to the critical level. In case profits exceed the critical level (new) entrepreneurs will enter until the profit level decreases to the critical level. An important determinant of the critical profit level is the extent to which entrepreneurs want to be compensated for the risk they face. 
We give a numerical example to indicate the impact of a lack of either Kirznerian or Knightian entrepreneurship. Assume that the two markets are identical in size, $a_{i}=a_{j}=50$, and that the fixed costs parameter $\alpha$ and critical profit level $\pi^{*}$ both equal one. The variable costs parameter $\beta$ is assumed to be 0.1 . The total number of retailers in each of the two markets is then derived from $a_{x} / N_{x}^{2}-\alpha=\pi^{*}$ and is found to equal five after inserting the numerical values. The total output of the two markets is derived from (3) to equal 800 .

Now assume that instead of both markets having five firms that there is one market with six and one market with four firms. Total output then equals 792 instead of the maximum output of 800 . Hence, the consequence of at least one of the six retailers not being alert to the prevailing disequilibrium entails a output loss of one percent. The lack of Kirznerian entrepreneurship that would otherwise have alerted one retailer to change location (market) leads to lower output. ${ }^{12}$ Now assume instead that entrepreneurs want to have a $(50 \%)$ higher compensation for the uncertainty they are confronted with and that the critical profit level $\pi^{*}$ equals 1.5 instead of 1 . The number of firms is each market then reduces to 4.47 and total output drops to 776 . Hence, the consequence of entrepreneurs being more averse to risk is a drop in total output. A decrease in the number of individuals prepared to take risks in the marketplace (Knightian entrepreneurs) leads to an output loss. ${ }^{13}$ The next section will elaborate on this issue: Choosing between entrepreneurship and employment.

\section{The Effects of THE ChoICE Between Entrepreneurship AND EMPLOYMENT}

In this section we present a simple model of occupational choice in which the impact of entrepreneurial activities is analyzed by considering the consequence of not allowing firms to enter (or exit) or of not allowing firms to expand (or to limit) their activities. We distinguish between three possible economic "systems" labeled "market economy", "semi-planned economy" and "planned economy". Before presenting the details of the occupational choice model, we will first discuss important recent papers concerning the intertemporal relation between occupational choice and economic development.

We will briefly discuss the contributions made in three articles: Banerjee and Newman (1993), Iyigun and Owen (1999) and Lloyd-Ellis and Bernhardt

\footnotetext{
${ }^{12}$ Yu (1998) provides an interesting analysis of the importance of Kirznerian (adaptive) cntrepreneurship in explaining Hong Kong's economic development. He finds that the small Hong Kong firms are usually the first groups to get out of a declining sector and move into new markets. He claims that the diversification of Hong Kong's economy into the service sector "can be explained consistently by the dynamic operations of adaptive entrepreneurship" (pp. 902-903).

${ }^{13}$ Ilmakunnes and Kanniainen (2001) find empirical cvidence for OECD countries to support the Knightian view that economic risks shape equilibrium entrepreneurship in an occupational choice model. They find evidence of both "national economic risk" (changes in GDP) and social insurance for labor risks (unemployment compensation), assumed not to be available to selfemployed, to negatively impact the rate of self-employment.
} 
(2000). The papers deal with the complicated issue of the two-way interaction between occupational choice and economic development. On the one hand, both the number of individuals choosing to become self-employed and their entrepreneurial skills affect economic development. On the other hand, the process of development affects the returns to occupations. It transforms the nature of risks and the possibilities for innovation.

Banerjee and Newman (1993) develop a model in which the distribution of wealth plays a central role. They assume that occupational decisions are dependent upon the distribution of wealth because of capital market imperfections, due to which poor agents can only choose working for a wage and wealthy agents become entrepreneurs. The initial distribution of wealth determines whether in the long run an economy converges to a case of only self-employment in small-scale production ("stagnation") or to one where an active labor market and both large- and small-scale production prevail ("prosperity"). Banerjee and Newman stress that the model implies that the initial existence of a population of dispossessed, whose best choice is to work for a wage, is the condition needed for an economy to achieve the stage of prosperous capitalism.

Whereas Banerjee and Newman focus on financial requirements as the defining characteristic of entrepreneurship, Iyigun and Owen (1999) focus on the element of risk. Iyigun and Owen distinguish between two types of human capital: Entrepreneurial and professional. Entrepreneurial activities are assumed to be more risky than professional activities. ${ }^{14}$ Entrepreneurs in the model accumulate human capital through a work-experience intensive process, whereas professionals' human capital accumulation is education-intensive. The models predicts that, as technology improves, individuals devote less time to the accumulation of human capital through work experience and more to the accumulation of human capital through professional training. The allocation of an increasing share of time to formal education continues until a steady state is reached (see Iyigun and Owen, p. 224). Hence, entrepreneurs would play a relatively more important role in intermediate-income countries and professionals are relatively more abundant in rich countries. However, both entrepreneurship and professional activities are important and those countries that initially have too little of either entrepreneurial or professional human capital may end up in a development trap. Iyigun and Owen point at former communist countries as an example of economies that have a highly educated labor force but that still not achieve the high-income steady state due to a shortage of entrepreneurs (p. 225).

Lloyd-Ellis and Bernhardt (2000) also derive how the scarcity or abundance of entrepreneurial skills is the defining variable behind the equilibrium development process. In their model, individuals may choose between working as

\footnotetext{
${ }^{14}$ The uncertainty in the return to entrepreneurial ventures is that with probability $q$ an individual achieves an income of $\lambda_{1}$, the endogenously determined technology level, times his entrepreneurial capital and with probability $1-q$ he receives no income. There is no uncertainty assumed in the return to education, being $\lambda_{1}$ times their professional capital (see Iyigun and Owen, p. 220).
} 
entrepreneurs, wage laborers in industry or in subsistence agriculture. Just like in the Banerjee and Newman model entrepreneurs are faced with a limited capital market and (inherited) wealth is needed to permit entrepreneurial activity to expand. The econony in the model goes through four separate stages. An interesting outcome of the model is that the average firm size rises quickly in the first stages of the development process, but then falls in the later stages of the development process. The number of entrepreneurs (outside agriculture) as a fraction of population may rise in each of the stages (Lloyd-Ellis and Bernhardt, p. 157).

We will present a simple new model of occupational choice in which the impact of entrepreneurial activities is analyzed by considering the consequence of not allowing firms to enter (or exit) or of not allowing firms to expand (or to limit) their activities. We distinguish between three possible economic "systems". In the first system, labeled "market economy", there is complete freedom of entry and exit and of firms adjusting their inputs to maximize profits. In this system there is complete entrepreneurial and managerial freedom. In the second system, labeled "semi-planned economy", there is no freedom of entry or exit. However, firms are free to adjust their input quantities so as to achieve maximum profits. In such an economic system the large incumbent firms are considered as the engines of economic progress. Starting new enterprises is hampered by regulations and by relatively low esteem of business ownership. The third economic system, labeled "planned economy", has also lost its managerial freedom of adjusting inputs to maximize profits. Firms are assigned to produce output using a certain fixed amount of labor even though it may lead some firms to be unprofitable.

Clearly, the three economic "systems" are extremes. However, comparing the economic performance of such virtual systems may enhance our understanding of the total contribution of entrepreneurial activity on the long and short term on economic performance. In addition, the conditions in the three systems may approximate actual conditions in existing economic systems. For example, the market economy of the United States grants (potential) entrepreneurs considerable freedom with little government intervention. In contrast, the economies of Continental Europe, like France and Germany and the Scandinavian countries, have a much larger role for government. In these countries government has actively intervened to support large enterprises in the recent past. The Soviet type of economic systems is the prime example of the planned economy system. The model described below is used to compare the relative performance of the three "systems". ${ }^{15}$ The non-mathematically interested reader may want to proceed with the last paragraph of this section in which we discuss the main results.

Consider a population of $N$ individuals that can choose between being an employee and being a manager (business owner). Each person $i$ is assigned a

\footnotetext{
${ }^{15}$ The model is only concerned with occupational choice, not with the (dis)incentives present in economic "systems" to pursue product or process innovation.
} 
certain managerial ability $e_{i t}$ in period $t$. This ability can be used in combination with an input of $L_{i t}$ employees earning an equal wage $w_{t}$ to produce a total output of some (homogeneous) good $Q_{i t}=e_{i t} L_{i t}^{\beta}$ with $\beta$ in between zero and one. Assuming the price of the good to be unity total profit for manager $i$ in period $t$ will be $\pi_{i t}=e_{i t} L_{i t}^{\beta}-w_{t} L_{i t}$. From the first order condition $\left(\partial \pi_{i t} / \partial L_{i t}=0\right)$ we find the optimal levels of labor input and profit:

$$
L_{i t}^{*}=\left(\beta e_{i t} / w\right)^{1 /(1-\beta)}
$$

and

$$
\pi_{i t}^{*}=(1-\beta) e_{i t}\left(\beta e_{i t} / w\right)^{\beta /(1-\beta)} .
$$

From equation (8) it is clear that individuals with higher levels of managerial ability will have higher profits $\left(\partial \pi_{i t}^{*} / \partial e_{i t}>0\right)$. In case individuals are free to enter and/or exit we would see incumbents exiting the market (and becoming employee) in case their optimal level of profits is less than the wage level, while employees would start enterprises in case their optimal level of profit would exceed their wage level. In conformity with Lucas (1978) an equilibrium is reached where individuals become managers if and only if

$$
e_{i t}>\frac{w_{t}}{\beta^{\beta}(1-\beta)^{1-\beta}}
$$

In each of the three economic systems it is assumed that the wage level is determined by the equilibrium condition of demand and supply of labor to be identical. If we denote the number of managers/entrepreneurs by $M_{t}$ and their set by $\Theta_{t}$, then this condition reads

$$
N-M_{t}=\sum_{i \in \Theta_{t}} L_{i t}^{*} \Leftrightarrow w_{t}=\beta\left(\sum_{i \in \Theta_{t}} e_{i t}^{1 /(1-\beta)} /\left(N-M_{t}\right)\right)^{1-\beta} .
$$

From equations (9) and (10) the equilibrium structure given free entry and exit can be determined. Given the distribution of the abilities $e_{i t}$ the equilibrium occupational choice and (maximum) total output can be derived. In case of changes in the ability distribution the manner in which equilibrium on the labor market is restored differs across the economic systems. In case of the "market economy" system there will be entry of managers with increased ability and exit of managers with decreased ability, changes in firm sizes and changes in the wage level. In case of the "semi-planned economy" system there will be changes in firm sizes of incumbents and changes in the wage level. The one variable that restores equilibrium in the "planned economy" system is the wage level because of the absence of managerial discretion to adapt labor demand. It is obvious that due to larger "degrees of freedom" the total output after changes in the ability distribution will be highest for the "market economy" and smallest for the "planned economy". The differences between the performances will be larger, the more the ability distribution changes over time. Hence, in periods of important changes in technological regimes and on the 
longer term the differences are likely to be largest. This finding is related to that presented by Eliasson (1995) that lack of new entry of firms will adversely impact economic performance not so much on the short term but in the long term.

\section{Entrepreneurship in Endogenous Growth Models}

One of the reasons that entrepreneurship disappeared from economic theory is that it played no role in the neoclassical growth model as developed by Solow (1970). An important characteristic of this growth model is that technological improvements are exogenous and therefore independent of economic incentives. Economic growth in the traditional growth models is achieved by capital accumulation and exogenous technological progress, both of which leave little room for any entrepreneurial role whatsoever (see also Baumol, 1968). The more recently developed endogenous growth models also support the idea that improvements in technology have been the key force behind perpetually rising standards of living. However, this long-term growth process is assumed in many endogenous growth models to be determined by purposive, profit-secking investment in knowledge (Grossman and Helpman, 1994, p. 24). The act of seeking profits by shifting resources to achieve improvements in technology can be seen as an entrepreneurial act because the outcome of the investments is uncertain. However, it is not common for endogenous growth models to explicitly address the issue of entrepreneurship as driving force of technological and economic development. We will discuss three exceptions in this section. The first exception is the Aghion and Howitt's (1992) model of creative destruction (see also Aghion and Howitt, 1997; Howitt and Aghion, 1998). The second exception is the endogenous market structure model by Peretto $(1998,1999 \mathrm{a}, 1999 \mathrm{~b})$, and the third exception is the imitation model developed by Schmitz (1989). Of these three exceptions the model by Aghion and Howitt has been the most influential and we will discuss it in some detail.

Aghion and Howitt introduce the notion of Schumpeterian "creative destruction" into a growth model by having firms investing resources in research to achieve a new product that renders the previous product obsolete. ${ }^{16}$ Capital is excluded from the basic model and growth results from technological progress, being a result from competition among firms that generate innovations. Firms are motivated by the prospect of (temporary) monopoly rents after a successful innovation is patented. A next innovation will again destroy these rents as the existing good is being made obsolete by the Schumpeterian entrepreneur. We will discuss a simple version of the basic model as presented by Aghion and

\footnotetext{
${ }^{16}$ It may be argued that Schumpeterian entrepreneurship cannot be modelled using the standard assumptions of the neo-classical model like profit maximization. It is evident that the Aghion and Howitt models fail to do complete justice to Schumpeter's discussions of the motivations that underlie entrepreneurial behaviour. We are grateful to the referee of this chapter for pointing this out.
} 
Howitt in their section 2 . The non-mathematically interested reader may want to proceed below equation (5.8).

Assume that there are four different kinds of units: A final consumption good $y$, an intermediate good $x$, unskilled labor used to produce the final good and skilled labor that can be used to produce the intermediate good or that can be used in research. The total amount of unskilled labor is fixed at $M$. The total amount of skilled labor is fixed at $N$ and the amount used to do research is denoted by $n$, leaving $N-n$ units for production of the intermediate good. The final good is assumed to be produced using a Cobb-Douglas type of production function (with input factors unskilled labor and intermediate goods) and, since $M$ is fixed, it can be written as

$$
y_{t}=A_{t} x_{t}^{\alpha} \quad 0<\alpha<1
$$

where $t$ is the index of period. The parameter $A_{t}$ denotes the productivity of the intermediate input in period $t$. The intermediate good is produced using skilled labor, not used for research, and linear technology:

$$
x_{t}=N-n_{t}
$$

Innovations arrive in a random sequence, with the Poisson arrival rate of innovations in the economy equal to $\lambda n_{t}$ (see also Howitt and Aghion, 1998, equation (6)). The arrival rate depends only upon the current flow of input to research. Hence, there is no memory in the technology of research. The index $t$ of period increases by one each time a new innovation has arrived, hence it is not a time index. The length of the time interval from $t$ to $t+1$ is random and has an exponential distribution with parameter $\lambda n_{t}$. During this time interval prices and quantities are assumed to be constant. Each innovation (the invention of a new intermediate good) makes the previous intermediate good obsolete because it allows the production of the final good $y_{t}$ to become more efficient. The increase in efficiency is determined by the factor $\gamma$ :

$$
A_{t}=A_{0} \gamma^{t} \quad \gamma>1 \text {. }
$$

The model is a "winner takes it all"-model in the sense that a successful innovator is assumed to obtain a patent used to monopolize the intermediate sector. The patent lifespan is assumed to be infinite but the monopoly lasts only till the next innovation when the intermediate good is replaced by the next vintage. Each market is assumed to be perfectly competitive with the exception of the monopolized intermediate sector.

The successful innovator has a temporary monopoly and seeks to maximize its profit during this interval. The final good sector will choose the amount of intermediate goods, $x_{t}$, so as to maximize $y_{t}-p_{t} x_{t}$ with the price of the final good as the "numérair" and $p_{t}$ being the price charged by the monopolist. The first order condition is

$$
p_{t}=\alpha_{t} A_{t} x_{t}^{\alpha-1}
$$

The monopolist takes this condition into account and maximizes its own 
profit $\left(\alpha A_{t} x_{t}^{\alpha-1}-w_{t}\right) x_{t}$ with $w_{t}$ being the wage level of skilled labor. The optimization gives as outcomes for profit, price and output of the intermediate good:

$$
\pi_{t}=\left(\frac{1-\alpha}{\alpha}\right) w_{t} x_{t}, \quad p_{t}=w_{t} / \alpha \quad \text { and } \quad x_{t}=\left(\frac{w_{t}}{\alpha^{2} A_{t}}\right)^{1 /(\alpha-1)} .
$$

We now turn to the amount of resources devoted to research, $n_{t}$. Because of constant returns to scale in the technology of research, the number of firms performing research is indeterminate. The firm(s) that employ(s) $n_{t}$ units of skilled labor performing research activities to achieve monopoly in period $t+1$ will have an instantaneous probability $\lambda n_{t}$ of having a successful innovation with instantaneous value $V_{t+1}$ (which does not depend upon $n_{t}$ ). The expected flow of profits equals $\lambda n_{t} V_{t+1}-w_{t} n_{t}$ which is maximized for $n_{t} \geq 0$. Because the research sector is perfectly competitive $\lambda V_{t+1}$ equals the wage level $w_{t} \cdot{ }^{17}$

The value $V_{t+1}$ is the expected present value of the flow of monopoly profits $\pi_{t+1}$, or

$$
V_{t+1}=\frac{\pi_{t+1}}{r+\lambda n_{t+1}} \quad r>0
$$

with $r$ being the constant rate of time preference. Equation (16) reveals the important characteristic of the Aghion and Howitt model that current research negatively depends upon future research: Creative destruction discourages current research because the prospect of monopoly rents is diminished.

The intertemporal relation between $n_{t}$ and $n_{t+1}$ is determined by substituting equations (12), (15) and (16) into the condition $w_{t}=\lambda V_{t+1}$. This results in

$$
1=\lambda \frac{\left(\frac{1-\alpha}{\alpha}\right) \gamma\left(\frac{N-n_{t+1}}{N-n_{t}}\right)^{\alpha-1}\left(N-n_{t+1}\right)}{r+\lambda n_{t+1}} .
$$

We now concentrate upon the (unique) stationary equilibrium in which $n_{t}=$ $n_{t+1}=\hat{n}$. From equation (17) we then derive the stationary equilibrium value

$$
\hat{n}=\frac{\gamma(1-\alpha) / \alpha}{1+\gamma(1-\alpha) / \alpha} N-\frac{r}{\lambda(1+\gamma(1-\alpha) / \alpha)} .
$$

Equation (18) shows a direct connection between research in stationary equilibrium $\hat{n}$ and the degree of market power. The higher the value of $\alpha$ the lower is the degree of market power. Specifically, $1-\alpha$ is the Lerner index (price minus marginal costs divided by price). Hence, some extent of market power to achieve rents is needed for Schumpeterian entrepreneurs to engage into research. Aghion and Howitt (1992, p. 336) derive the average growth rate of real output to be $\lambda \hat{n} \ln (\gamma)$. The effect of market power attracting entrepreneur-

\footnotetext{
${ }^{17}$ We do not discuss the possibility of the wage level being less than $\lambda V_{t+1}$.
} 
ial energy shows the importance of imperfect competition for the growth process.

Competition and growth are inversely related in this Schumpeterian model, something usually not supported by empirical evidence (for instance, see Nickell, 1996). Aghion and Howitt (1997), therefore, extend their model to show that a more competitive market structure may contribute to economic growth. In Howitt and Aghion (1998), the authors add capital to their model of creative destruction. They show that capital accumulation and innovation are complementary processes and equal partners in the growth process. Aghion and Howitt have contributed to the endogenous growth literature by connecting purposive, profit-seeking investment in knowledge to the persons performing this task: Entrepreneurs.

In a series of papers Peretto introduces a different kind of endogenous growth model where an endogenous market structure is incorporated. His model has a key role for the number of firms, again in the intermediate sector, determining the returns to investment and $R \& D$. An important difference between his model and the model by Aghion and Howitt is the assumption that monopolistic firms in the intermediate sector set up in-house R\&D facilities to produce a continuous flow of cost-reducing innovations. This differs from the independent research firms in Aghion and Howitt (1992). The relation between the number of firms and returns to investment and R\&D in the Peretto (1999b) model is determined by a trade-off between external and internal economies of scale. External economies of scale are a result of complementarities across firms because aggregate output is increasing in the number of intermediate goods. ${ }^{18}$ A large number of firms in the model therefore leads to high specialization, large investment and R\&D programs, and fast growth. On the other hand, the fragmentation of the market due to a large number of firms leads to small investment and R\&D programs, and slow growth. An increase in the number of firms increases the market size through the specialization effect whereas each firm's market share is reduced through the fragmentation effect. As a consequence there is a hump-shaped relation between the number of firms and economic growth.

In Peretto (1998) entrepreneurs play a more visible role. His model seeks to explain a shift in the locus of innovation from $R \& D$ undertaken by inventorentrepreneurs ("competitive capitalism") to R\&D undertaken within established firms in close proximity to the production line ("trustified capitalism"). In the model the economy converges to a stable industrial structure where entrepreneurial R\&D and the formation of new firms peter out, while growth is driven while corporate R\&D undertaken by established oligopolists drives growth. ${ }^{19}$

\footnotetext{
${ }^{18}$ Peretto uses a Dixit-Stiglitz type of production function, exhibiting economies of specialization, with the homogeneous final good $y$ determined by the $N$ intermediate goods $x_{i}$ as: $y=\left(\left.\int_{0}^{N} x\right|^{(E-1) / \varepsilon} d i\right)^{c /(\varepsilon-1)}$.

${ }^{19}$ This is an excataion e/fect: The fall in the number of firms is due to technological opportunities leading firms to invest in R\&D which is characterized by sunk costs that make entry and incumbency more costly and labor more scarce for production.
} 
While it is true that from about 1870 till 1970 the corporate laboratories affiliated with large manufacturing firms have been increasingly responsible for commercial $\mathrm{R} \& \mathrm{D}$, the disappearance of entrepreneurial energy as important determinant of economic growth is an unrealistic feature of the model. In Peretto's setup entrepreneurs must develop new differentiated products since entering an existing product line in Bertrand competition with the incumbent is bound to lead to losses because of sunk entry costs. Entrants are net creators of knowledge, as "they create a new product and the knowledge necessary to run manufacturing operations" (p. 58). Although in more developed stages the economy in Peretto's model experiences a transition from entrepreneurial to corporate R\&D, entrepreneurship plays a vital role in economic development: Only when a critical number of firms have entered the market, established firms begin investing in R\&D. A key result of Peretto's models is that "there is an inverted- $U$ relationship between the number of firms and steady-state growth" (Peretto, 1999a, p. 1762).

Schmitz (1989) was the first to present an endogenous growth model that relates entrepreneurial activity and economic growth. However, his entrepreneurs are more "passive" than in the other models because their role is restricted to that of "imitation". This may have contributed to the Schmitz model being less influential than the Aghion and Howitt model. His model implies that the equilibrium fraction of entrepreneurs in an economy is lower than the social optimal level, providing a rationale for policies stimulating entrepreneurial activity. We end this section stressing that one may also set up endogenous growth models in which (a specific notion of) entrepreneurship may not be beneficial to growth. Peng (2000) constructs such a model in which entrepreneurs do not carry out research, but choose between research projects. $\mathrm{He}$ finds a negative relationship because of the rent-seeking element in the exercise of entrepreneurship. ${ }^{20}$

\section{EMPIRICAL EVIDENCE}

There are various strands in the empirical literature showing the effect of entrepreneurship on economic growth. We will concentrate on four strands of empirical research. ${ }^{21}$ The first deals with the question of the effect of turbulence on economic growth. Turbulence, viz., the sum of entry and exit in industries or regions, can be interpreted as an indicator of entrepreneurial activity. The

\footnotetext{
${ }^{20}$ The idea that entrepreneurial energy as such may not suffice for economic progress was also expressed by Baumol (1990) stressing the importance of entrepreneurship being led into productive channels.

${ }^{21}$ The Global Entrepreneurship Monitor (GEM) research program (Reynolds et al., 2001) is yet a different approach. It seeks to assess the level of national entrepreneurial activity and to relate this to the rate of economic growth. Entrepreneutial activity is measured through questionnaires in 29 countries in 2001,21 countries in 2000 and 10 countries in the first year of assessment, 1999. The research program shows some preliminary evidence of the level of entrepreneurial activity to be associated with economic growth.
} 
second strand concentrates on the effect of (changes in) the size-distribution in regions on subsequent economic growth. In case a region has a larger share of small firms when compared to another region this could indicate a higher level of entrepreneurial activity. The third strand investigates the effect of the number of market participants in an industry on economic growth. An increase in the number of competitors is usually related to more intensive entrepreneurial activity. The fourth strand of empirical literature concentrates on the effect of the number of self-employed (business owners) on subsequent growth. In developed economies the rate of self-employment will be related to the extent of entrepreneurial activity. New firms usually start with a phase of self-employment sensu stricto, viz., with no paid employees. A fifth and last source of evidence on the relation between self-employment and progress is the economic history of the formerly centralized planned economies. A characteristic of these economies was the almost complete absence of small firms (and private ownership of the means of production), and this extreme monopolization constituted one of the major factors leading to the collapse of state socialism (Acs, 1996). The development of small enterprises is considered a vital part of the current transition process in Eastern Europe. This last source of evidence will not be discussed in the present chapter. ${ }^{22}$

The empirical evidence of the effect of turbulence on subsequent economic growth is mixed. Caves (1998, p. 1973) concludes that in the short run, turnover from entry and exit appears to make only a very small contribution to an industry's productivity growth. However, he adds that in the long run, the entry-exit turnover makes a more important contribution. Bosma and Nieuwenhuijsen (2000) use data for 40 Dutch regions for the 1988-96 period and find that turbulence positively affects total factor productivity growth in the service sector but not so in manufacturing.

A different literature has focused on the impact of entrepreneurship on subsequent economic performance, at the regional level. The unit of observation for these studies is at the spatial level, either a city, region, or state. The most common and most exclusive measure of performance is growth, typically measured in terms of employment growth. These studies have tried to link various measures of entrepreneurial activity, most typically startup rates, to economic growth. Other measures sometimes used include the relative share of SMEs, and self-employment rates.

Reynolds (1999) finds some evidence for turbulence to be related to economic growth using American Labor Market Area data for the 1980-92 period. Labor Market Areas generally include a metropolitan area and the surrounding rural area from which it draws both employees and consumers. Acs and Armington (2002) link a measure of entrepreneurship to growth at the Labor Market Area level. Their measure of entrepreneurial activity is the new firm birth rate in each of these local economies. They test the hypothesis that increased entrepre-

\footnotetext{
${ }^{22}$ The role of entreprencurship in transition economies is discussed in e.g. Nolan (1995) and McMillan and Woodruff (2002).
} 
neurial activity leads to higher growth rates of local economies. They find that the higher levels of entrepreneurial activity are strongly positively associated with higher growth rates, even after controlling for establishment size, and agglomeration effects.

Audretsch and Fritsch (1996) analyzed a database identifying new business startups and exits from the social insurance statistics in Germany to examine whether a greater degree of turbulence leads to greater economic growth. Each record in the database identifies the establishment at which an individual is employed. The startup of a new firm is recorded when a new establishment identification appears in the database, which generally indicates the birth of a new enterprise. While there is some evidence for the United States linking a greater degree of turbulence at the regional level to higher rates of growth for regions (Reynolds, 1999), Audretsch and Fritsch (1996) find that the opposite was true for Germany during the 1980s. In both the manufacturing and the service sectors, a high rate of turbulence in a region tends to lead to a lower and not a higher rate of growth. They attribute this negative relationship to the fact that the underlying components - the startup and death rates - are both negatively related to subsequent economic growth. Similar evidence for Germany is found by Fritsch (1997).

Audretsch and Fritsch (1996) conjectured that one possible explanation for the disparity in results between the United States and Germany may be the extent of innovative activity in terms of new-firm startups and the ability of new firms to ultimately displace the incumbent enterprises. It may be that innovative activity did not play the same role for the German Mittelstand as it does for SMEs in the United States. To the degree that this was true, it may hold that regional growth emanates from SMEs only when they serve as agents of change through innovative activity.

Divergent findings from the 1980 s about the relationship between the degree of entrepreneurial activity and economic growth in the United States and Germany posed something of a puzzle. On the one hand, these different results suggested that the relationship between entrepreneurship and growth lacks a general pattern across developed countries. On the other hand, it also provided evidence for the existence of distinct and different national systems capable of supporting economic growth. Convergence in growth rates seemed to be attainable even when maintaining differences in underlying institutions and structures.

However, in a more recent study, Audretsch and Fritsch (2002) find that different results emerge for the 1990s. Those regions with a higher startup rate exhibit higher growth rates. This would suggest that, in fact, Germany is changing over time, where the engine of growth is shifting towards entrepreneurship as a source of growth.The results of their 2002 paper suggest a somewhat different interpretation. Based on the empirical evidence that the source of growth in Germany has shifted away from the established incumbent firms during the 1980 s to entrepreneurial firms in the $1990 \mathrm{~s}$, it would appear that a process of convergence is taking place between Germany and the United 
States, where entrepreneurship provides the engine of growth in both countries. Despite remaining institutional differences, the relationship between entrepreneurship and growth is apparently converging in both countries.

Audretsch and Keilbach (2002) include a measure of entrepreneurship capital in estimating a production function model for Germany. They find that the degree of entrepreneurship capital has a positive impact on growt in Germany.

The positive relationship between entrepreneurship and growth at the regional level is not limited to Germany in the 1990. For example, Foelster (2000) examines not just the employment impact within new and small firms, but the overall link between increases in self-employment and total employment in Sweden between 1976 and 1995. By using a Layard-Nickell framework, he provides a link between micro behavior and macroeconomic performance, and shows that increases in self-employment rates have had a positive impact on regional employment rates in Sweden.

Hart and Harvey (1995) link measures of new and small firms to employment generation in the late 1980s for three regions in the United Kingdom. While they find that employment creation came largely from SMEs, they also identify that most of the job losses also came from SMEs. Callejon and Segarra (1999) use a data set of Spanish manufacturing industries between 1980 and 1992 to link new-firm birth rates and death rates, which taken together constitute a measure of turbulence, to total factor productivity growth in industries and regions. They adopt a model based on a vintage capital framework in which new entrants embody the edge technologies available and exiting businesses represent marginal obsolete plants. Using a Hall type of production function, which controls for imperfect competition and the extent of scale economies, they find that both new-firm startup rates and exit rates contribute positively to the growth of total factor productivity in regions as well as industries.

The empirical evidence of the effect of (changes in) the size distribution of firms on subsequent growth performance appears more clear-cut, at least for data of the late 1980s and early 1990s. Carree and Thurik $(1998,1999$ a) show that the share of small firms in manufacturing industries in European countries in 1990 has had a positive effect on the industry output growth in the subsequent four years. Thurik (1996) reports that the excess growth of small firms ${ }^{23}$ has had a positive influence on percentage change in gross national product for a sample of 16 European countries in the period 1988 through 1993. Robbins, Pantuosco, Parker and Fuller (2000) perform an analysis of 48 U.S. states for the 1986-95 period and find that states with a higher proportion of (very) small business employment experience higher level of productivity growth and Gross State Product growth. Audretsch, Carree, van Stel and Thurik (2002) find evidence for 17 European countries that the consequences for economic growth of not shifting the industry structure away from large business towards small business have been rather large. Likewise, Carree (2002) shows evidence for

\footnotetext{
${ }^{23}$ The excess growth of small firms in that study is defined as the percentage change in the valueof-shipments accounted for by small firms minus that accounted for by large firms.
} 
the five largest economies (France, Germany, Japan, U.K. and U.S.) that manufacturing industries that underwent only little downsizing in the 1977-90 period experienced less subsequent growth when compared internationally.

Nickell (1996), Nickell, Nicolitsas and Dryden (1997) and Lever and Nieuwenhuijsen (1999) present evidence that competition, as measured by increased number of competitors, has a positive effect on the rate of total factor productivity growth. This positive effect is in line with Geroski's (1989) finding of overall productivity growth in 79 U.K. manufacturing industries to increase with the lagged rate of gross entry of new firms. One reason for these findings is that an increased number of market participants and increased entrepreneurial activity often go hand in hand. There have been some studies on the impact of the number of market participants on regional economic growth as well. Glaeser, Kallal, Scheinkman and Shleifer (1992) examine three determinants of regional sectoral growth: Specialization, diversity and competition. They find that local competition, measured as the relative number of businesses per worker, encourages employment growth in industries. Fritsch (1997) and Audretsch and Fritsch (2002) relate start-up activity in German regions to subsequent growth. They find that for Germany the impact of start-up activity on economic growth was absent in the 1980s but became positive in the 1990s.

A fourth strand of literature has started to focus upon the effect of selfemployment on growth. Blanchflower (2000, p. 497) finds no evidence for a panel of OECD countries of increases in the self-employment rate to increase economic growth. However, he uses uncortected OECD Labor Force Statistics data suffering from lack in comparability across countries and, in a list of additional cases, lack in comparability over time due to changes in counting procedures. In a recent paper Carree, van Stel, Thurik and Wennekers (2002) investigate whether countries that deviate from an "equilibrium" business ownership rate for comparable levels of economic development suffer in terms of economic growth. In their view deviations between the actual and the "equilibrium" rate of business ownership will diminish the growth potential of an economy in the medium term. A shortage of business owners is likely to diminish competition with detrimental effects for static efficiency and competitiveness of the national economy. It will also diminish variety, learning and selection and thereby harm dynamic efficiency (innovation). On the other hand, a glut of self-employment will cause the average scale of operations to remain below optimum. It will result in large numbers of marginal businesses, absorbing capital and human energy that could have been allocaled more productively elsewhere. They develop an error-correction model to determine the "equilibrium" rate of business ownership as a function of GDP per capita. ${ }^{24}$ Their estimated "equilibrium" relationship, using corrected OECD Labor Force Statistics data, is presented in Figure 2 together with the actual (corrected)

\footnotetext{
${ }^{24}$ Carree, van Stel, Thurik and Wennekers hypothesize an "equilibrium" relationship between the rate of business ownership and per capita income that is U-shaped, but in fact find it to be impossible to statistically discriminate U-shaped "equilibrium" functions from L-shaped functions.
} 


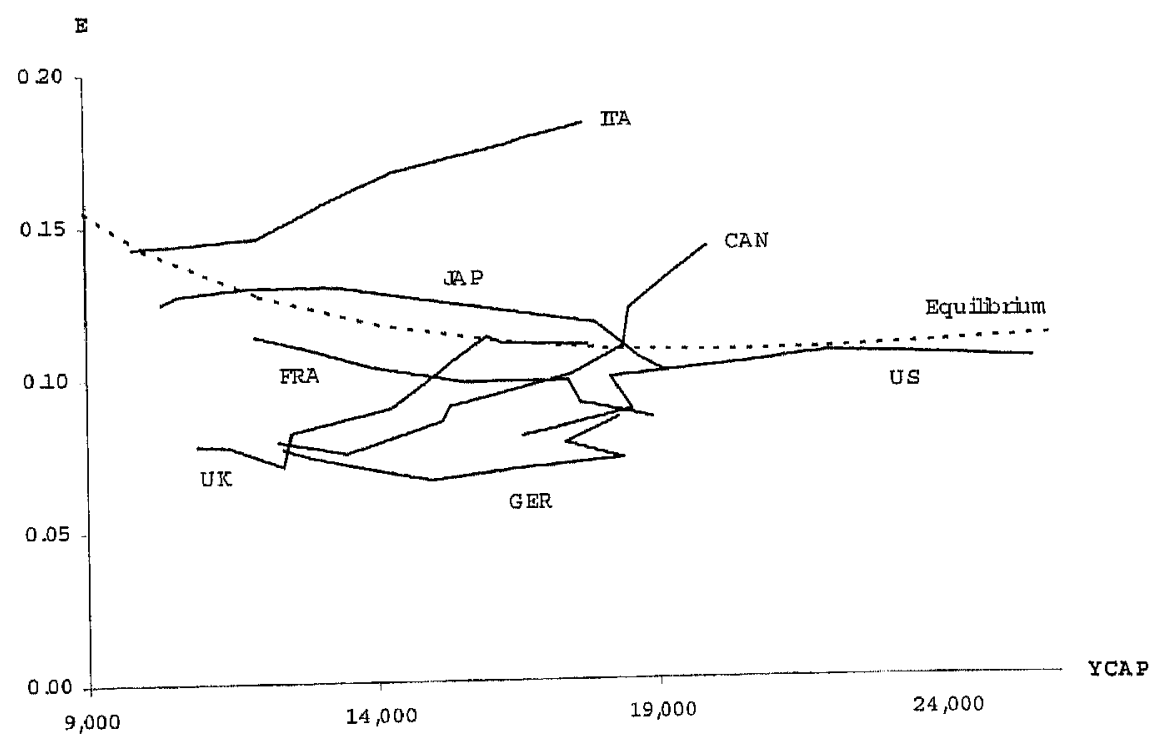

Figure 2. The actual and equilibrium rate of business ownership for G7-countries, 1972-1998

Note: E stands for the ratio of self-employed over labor force. YCAP stands for GDP per capita in US dollars (or 1990).

Source: Carree, van Stel, Thurik and Wennekers (2002).

data of the G7-countries. The estimation results show that a deviation of the actual number of business owners from the "equilibrium" rate has a significantly negative impact on economic growth.

Figure 2 shows that most countries had too few self-employed relative to the equilibrium value. An obvious exception is Italy. It indicates that the high level of self-employment in Italy is not efficient: It has a relatively large negative impact on economic growth. ${ }^{25}$ Countries with a low business ownership rate compared to the equilibrium include the Scandinavian countries. These economies are characterized by a large public sector, relatively low entry and exit rates and high taxes. Eliasson (1995) and Braunerhjelm and Carlsson (1999) blame part of Sweden's relatively bad economic performance in the 1980s on limited private initiative and a lack of structural adjustment. Another country with a relatively low business ownership rate is Germany. Figure 2 also shows that, at least until recently, Germany has failed to restructure where for example the United Kingdom has. Klodt (1990) blames (West) German industrial policy for repressing structural change in supporting large-scale industries with subsidies. An important reason for the lack of a vibrant sector of new firms and

${ }^{25}$ In Italy, research and development expenditures are by far the lowest among the largest OECD countries as a percentage of gross national product. This is in line with the idea that when there are too many business owners, the scale advantages in research and development are not utilized. See Cohen and Klepper (1996). 
industries in Germany up till the mid 1990s has been the high barriers to innovative activity (Audretsch, 2000).

It should be stressed that the number of self-employed is a possible yardstick of entrepreneurship as statistical information is often available along the ownership dimension. However, this yardstick can be misleading. For instance, it is unknown whether the relatively high number of self-employed in Italy as compared to Germany expresses a high level of Schumpeterian entrepreneurship or merely a time lag in economic development influencing the number of marginal establishments or merely differences in sectoral composition. In recent empirical studies other approximations are brought forward. Audretsch (1995) uses the employment share of surviving young firms as a proxy for entrepreneurial activity in manufacturing industries. This variable may well express the comparative entrepreneurial positions of these industries. Outside the manufacturing sector this variable may be biased due to the occurrence of franchising firms and marginal or part-time start-ups. Moreover, the rate of intrapreneurship, both in new and incumbent firms, is lacking.

\section{Future Analysis and Policy Issues}

We expect a framework relating entrepreneurial activity to economic growth to hinge on at least four elements. First, on the literature identifying the microeconomic foundations of growth emphasizing the role of knowledge externalities in the growth process (Romer, 1986 and 1994). Second, it should identify intermediate linkages like the ones mentioned in Figure 1. Third, it should deal with dual causality in the relation between entrepreneurial activity and growth. And finally, it should take into account the multidisciplinary character while linking together different levels of analysis. ${ }^{26}$ Before discussing some policy issues we will first present such a framework derived from Wennekers and Thurik (1999).

\section{A Framework for Futule Analysis}

Figure 3 presents a framework inspired by the many insights reaped from the various strands of the literature. Three levels of analysis are distinguished since linking entrepreneurship to economic growth also means linking the individual level to the firm and the macro level.

Entrepreneurial action happens at the firm level. Entrepreneurs need a vehicle transforming their personal qualities and ambitions into actions. Small firms where the entrepreneur has a controlling stake provide such a vehicle. Larger firms often mimic smallness (using organizational forms like business units, subsidiaries and joint ventures) to introduce corporate entrepreneurship

\footnotetext{
${ }^{26}$ See Audretsch, Thurik, Verheul and Wennekers (2002) for such a framework concerning the determinants of entrepreneurship.
} 


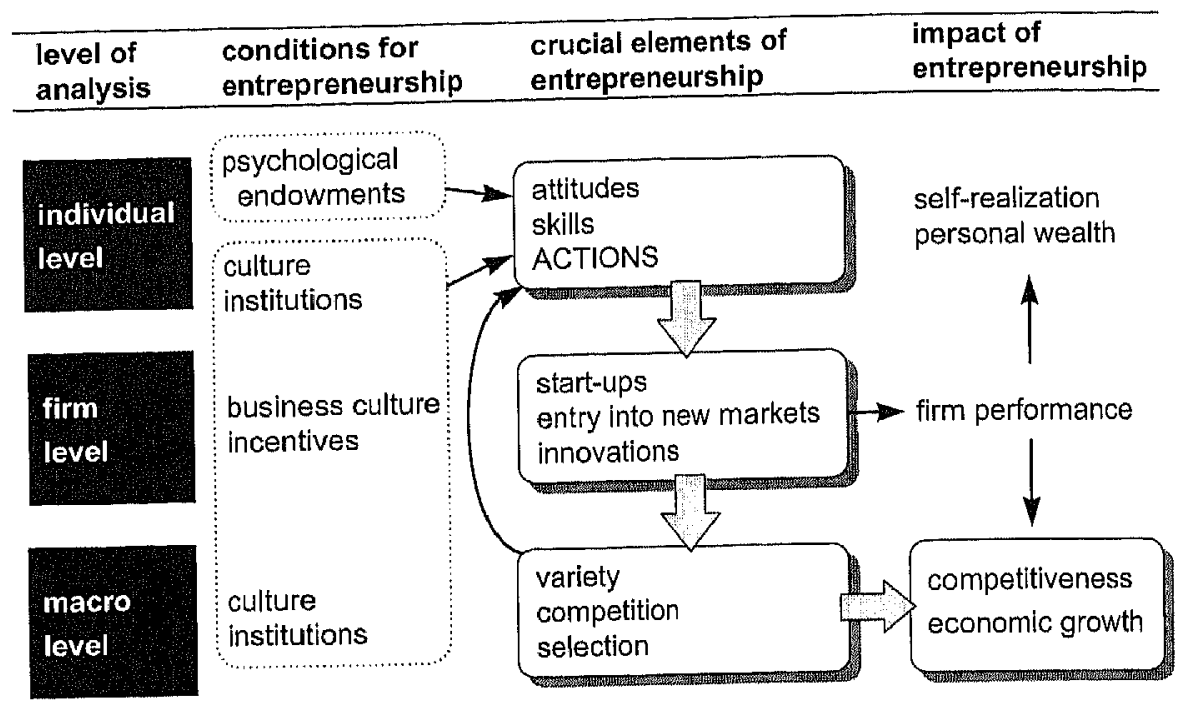

Figure 3. Framework for linking entrepreneurship to economic growth

Source: Wennekers and Thurik (1999).

or intrapreneurship. The outcomes of these entrepreneurial manifestations at the firm level generally have to do with "newness". This can be newness through product, process and organizational innovation, entry of new markets and innovative business start-ups.

At the aggregate level of industries, regions and national economies the many individual entrepreneurial actions compose a mosaic of new experiments. In evolutionary terms this can be termed variety. A process of competition between these various new ideas and initiatives takes place continuously leading to the selection of the most viable firms and industries. Variety, competition, selection and also imitation expand and transform the productive potential of a regional or national economy (by replacement or displacement of obsolete firms, by higher productivity and by expansion of new niches and industries).

In this process, Schumpeterian entrepreneurs, intrapreneurs and managerial business owners all play their part (see Table 1). Next to the linkages from the individual level to the aggregate level, there are important feedback mechanisms. Competition and selection amidst variety undoubtedly enable individuals (and firms) to learn from both their own and other's successes and failures. These learning processes enable individuals to increase their skills and adapt their attitudes. The outcome of these so-called spillovers will be new entrepreneurial actions, creating a recurrent chain of linkages.

Clearly, the outcome of these dynamic processes depends on a set of conditions like the ones referred to in Figure 3. First, this refers to the national (or regional) cultural environment, and to the internal culture of corporations. The linkages between culture and entrepreneurship are by no means simple and 
straightforward, and much is still unknown about these processes. The history of the rise and fall of nations has shown that cultural vitality, thriving sciences and high tide in entrepreneurship often coincide (Wennekers and Thurik, 1999). Second, the institutional framework, both on the national level and within firms, defines the incentives for individuals to turn their ambitions into actions, and determines to what extent unnecessary barriers will hamper them. The importance of institutions for the development of entrepreneurship is paramount and deserves further study.

\section{Some Policy Issues}

One of the central goals of public policy common among all modern economies is the generation of growth and the creation of employment. Much of the policy debate to generate growth and jobs has relied on a macro-economic framework and focused on the traditional macro-economic policy instruments. The survey of the present chapter suggests that a different, less traditional instrument for generating growth and employment plays an important role policies that generate and promote entrepreneurship (OECD, 1998). Empirical evidence surveyed in this chapter suggests that those countries that have experienced an increase in entrepreneurial activity have also enjoyed higher rates of growth. However, the actual mechanisms, i.e., the intermediate linkages, why entrepreneurship generates growth are less obvious. The present chapter relies on a rich body of literature, both theoretical and empirical, analyzing the micro foundations of entrepreneurship. Entrepreneurship generates growth because it serves as a vehicle for innovation and change, and therefore as a conduit for knowledge spillovers. Thus, in a regime of increased globalization, where the comparative advantage of modern economies is shifting towards knowledge-based economic activity, not only does entrepreneurship play a more important role, but also the impact of that entrepreneurship is to generate growth. This has led Yu to argue that "any policy recommendation on economic development should be based on an analysis that incorporates entrepreneurship, the engine of economic growth" (Yu, 1998, p. 906). Similarly, Holcombe claims that "the incorporation of entrepreneurship into the framework of economic growth not only fills in the institutional details to help make the growth process more understandable, but also points toward more promising economic policy recommendations for fostering economic growth" (Holcombe, 1998, p. 60).

As the comparative advantage in Western Europe and North America has become increasingly based on new knowledge, public policy towards business has responded in two fundamental ways. The first has been to shift the policy focus away from the traditional triad of policy instruments essentially constrain ing the freedom of firms to contract - regulation, competition policy or antitrust, and public ownership of business. The policy approach of constraint was sensible as long as the major issue was how to restrain footloose multinational corporations in possession of considerable market power. Instead, a new policy 
approach is emerging which focuses on enabling the creation and commercialization of knowledge (Audretsch and Thurik, 2001a). Examples of such policies include encouraging R\&D, venture capital and new-firm startups. The shift from constraining to enabling policies goes together with the shift from the Schumpeter Mark II regime to the Schumpeter Mark I regime. The second fundamental shift involves the locus of such enabling policies, which are increasingly at the regional or even local level. The last decade has seen the emergence of a broad spectrum of enabling policy initiatives that fall outside of the jurisdiction of the traditional regulatory agencies. See, for instance, the issues of the European Observatory for SMEs (EIM/ENSR, 1993 through 1997 and European Commission, 2000). ${ }^{27}$ The current decade will witness many more such enabling policies.

\section{ACKNOWLEDGEMENT}

The authors are grateful to Zoltan Acs, David Audretsch, Bruce Kirchhoff, Boris Lokshin and André van Stel for comments. The present chapter draws on a range of earlier research, viz. Carree and Thurik (1999b), Carree, van Stel, Thurik and Wennekers (2002), Wennekers and Thurik (1999), Audretsch, Verheul, Thurik and Wennekers (2002) and Audretsch and Thurik (2000, 2001a and 2001b). Martin Carree is grateful to the Royal Netherlands Academy of Arts and Sciences (KNAW) for financial support. Finally, the present paper is part of the SNS project on Entrepreneurship and Growth financed by the Marcus and Marianne Wallenberg's Foundation.

\section{REFERENCES}

Acs, ZJ. (1992). Small business economics: A global perspective. Challenge, 35, November/ December, pp, 38-44.

Acs, ZJ. (1996). Small firms and economic growth. In P.H. Admiral (ed.), Small Business in the Modern Economy. De Vries Lectures in Economics, Oxford, U.K.: Blackwell Publishers.

Acs, Z.J. and D.B. Audretsch (1987). Innovation, market structure, and firm size. Review of Economics and Statistics, 69, 567-574.

Acs, Z.J. and D.B. Audretsch (1990). Innovation and Small Firms. Cambridge, MA: MIT Press.

Acs, Z.J. and D.B. Audretsch (1993). Concl usion. In Z.J. Acs and D.B. Audretsch (eds.), Small Fimms and Entrepreneurship: An East-West Perspective. Cambridge, U.K.: Cambridge University Press.

Acs, Z.J., D.B. Audretsch and D.S. Evans (1994). The determinants of variation in the self-employment rates across countries and over time, mimeo (fourth draft).

Acs, Z.J. and C. Armington (2003). Endogenous Growth and Entrepreneurial Activity in Cities. Center for Economic Studies, CES 2003 January.

Aghion, P. and P. Howitt (1992). A model of growth through creative destruction. Econometrica, $60,323-351$.

${ }^{27}$ Sternberg (1996) documents how the suecess of a number of different high-technology clusters spanning a number of developed countries is the direct result of enabling policies, such as the provision of venture capital or research support. 
Aghion, P. and P. Howitt (1997). A Schumpeterian perspective on growth and competition. In D.M. Kreps and K.F. Wallis (eds.), Advances in Economics and Econonetrics: Theory and Applications, Vol. 2, pp. 279-317. Cambridge, UK: Cambridge University Press.

Aiginger, K. and G. Tichy (1991). Small firms and the merger mania. Small Business Economics, 3, 83-101.

Audretsch, D.B. (1995). Innovation and Industry Evolution. Cambridge, MA: MIT Press.

Audretsch, D.B. (2000). Entrepreneurship in Germany, In D.L. Sexton and H. Landström (eds.), The Blackwell Handbook of Entrepreneurship. Oxford, UK: Blackwell Publishers.

Audretsch, D.B. and M. Fritsch (1996). Creative destruction: Turbulence and economic growth in Germany. In E. Helmstadter and M. Perlman (eds,), Behavioral Norms, Technological Progress, and Economic Dynamics: Studies in Schumpeterian Economics, Ann Arbor: University of Michigan Press, pp. $137-150$.

Audretsch, D.B. and M. Fritsch (2002). Growth regimes over time and space. Regional Studies, $36,113-124$.

Audretsch, D.B. and M. Keilbach (2003). Entrepreneurship capital and economic performance, Centre for Economic Policy Research (CEPR) discussion paper No. 3678.

Audretsch, D.B. and A.R. Thurik (2000). Capitalism and democracy in the 21st century: From the managed to the entrepreneurial economy. Jounal of Evolutionary Economics, 10, 17-34.

Audretsch, D.B. and A.R. Thurik (2001a). What is new about the new economy?: Sources of growth in the managed and entrepreneurial economies. Industrial and Corporate Change, 10, 267-315.

Audretsch, D.B. and A.R. Thurik (2001b). Linking entrepreneurship to growth, STI working paper 2001/2. Paris: OECD.

Audretsch, D.B., M.A. Carree and A.R. Thurik (2001). Does entrepreneurship reduce unemployment? Discussion paper TI01-074/3. Tinbergen Institute, Erasmus University, Rotterdam.

Audretsch, D.B., M.A. Carree, A.J. van Stel and A.R. Thurik (2002). Impeded industrial restructuring: The growth penalty. Kyklos, 55, 81-98.

Audretsch, D.B., L. Klomp and A.R. Thurik (2002). Gibrat's Law: Are the services different? Report ERS-2002-04-STR, Erasmus Research Institute for Management, Erasmus University Rotterdam.

Audretsch, D.B., I. Verheul, A.R. Thurik and S. Wennekers (eds.) (2002), Entrepreneurship: Determinants and Policy in a European-US Comparison. Boston/Dordrecht: Kluwer Academic Publishers.

Banerjee, A.V. and A.F. Newman (1993). Occupational choice and the process of development. Jotrnal of Political Economy, 101, 274-298.

Baumol, W.J. (1968), Entrepreneurship and economic theory. American Economic Review, 58, 64-71.

Baumol, W.J. (1990). Entrepreneurship: Productive, unproductive and destructive. Journal of Political Economy, 98, 893-921.

Baumol, W.J. (1993). Formal entrepreneurship theory in economics: Existence and bounds. Journal of Business Venturing, 8, 197-210.

Berkowitz, D. and J. Holland (2001). Does privatization enlaance or deter small enterprise formation? Economics Letters, 74, 53-60.

Blanchflower, D.G. (2000). Self-employment in OECD countries. Labow Economics, 7, 471-505.

Blau, D. (1987). A time series analysis of self-employment. Joumal of Political Economy, 95, 445-467.

Bosma, N. and H. Nieuwenhuijsen (2000). Turbulence and productivity in the Netherlands, EIM research report 9909/E, EIM Small Business Research and Consultancy, Zoetermeer, the Netherlands.

Braunerhjelm, P. and B. Carlsson (1999). Industry structure, entrepreneurship and the macroeconomy: A comparison of Ohio and Sweden, 1975-1995. In Z.J. Acs, B. Carlsson and C. Karlsson (eds.), Entrepreneurship, Sinall and Mediun-Sized Enterprises and the Macroeconomy. Cambridge, UK: Cambridge University Press, pp. 137-158.

Brock, W.A. and D.S. Evans (1986). The Economics of Small Businesses: Their Role and Regulation in the U.S. Economy. New York: Holmes and Meier.

Brock, W.A. and D.S. Evans (1989), Small business economics. Small Business Economics, 1, 7-20. 
Bull, I. and G.E. Willard (1993). Towards a theory of entrepreneurship. Journal of Business Venturing, 8, 183-195.

Callejon, M. and A. Segarra (2000). Business dynamics and efficiency in industries and regions: The case of Spain. Small Business Economics, 13(4), 253-271.

Carlsson, B. (1989). The evolution of manufacturing technology and its impact on industrial structure: An international study. Small Business Economics, 1, 21-37.

Carlsson, B. (1992). The rise of small business: Causes and consequences. In W.J. Adams (ed.), Singular Europe, Economy and Policy of the European Conmunity after 1992. Ann Arbor, MI: University of Michigan Press, pp. 145-169.

Carlsson, B. (1996). Differing patterns of industrial dynamics: New Zealand, Ohio and Sweden, 1978-1994. Small Business Economics, 8, 219-234.

Carlsson, B. (1999). Small business, entrepreneurship, and industrial dynamics, In Z. Acs (ed.), Are Small Fints Important? Boston/Dordrecht: Kluwer Academic Publishers, pp. 99-110.

Carree, M.A. (2002). Industrial restructuring and economic growth. Small Business Economics, 18, 243-255.

Carree, M.A, and L. Klomp (1996). Small business and job creation: A comment. Small Business Economics, 8, 317-322.

Carree, M., A. van Stel, R. Thurik and S. Wennekers (2002). Economic development and business ownership: An analysis using data of 23 OECD countries in the period 1976-1996. Small Business Economics, 19, 271-290.

Carree, M.A. and A.R. Thurik (1998). Small firms and economic growth in Europe. Atlantic Economic Journal, 26(2), 137-146.

Carree, M.A. and A.R. Thurik (1999a), Ind ustrial structure and economic growth. In D.B. Audretsch and A.R. Thurik (eds.), Innovation, Industry Evolution and Employment. Cambridge, UK: Cambridge University Press, pp. 86-110.

Carree, M.A. and A.R. Thurik (1999b). The carrying capacity and entry and exit flows in retailing. Intemational Jotirnal of Industrial Organization, 17, 985-1007.

Caves, R.E. (1998). Industrial organization and new findings on the turnover and mobility of firms. Joumal of Economic Literature, 36, 1947-1982.

Chandler, A.D. Jr. (1990). Scale and Scope: The Dynamics of Industrial Capitalism. Cambridge, MA: Harvard University Press.

Cohen, W.M. and S. Klepper (1992). The trade-off between firm size and diversity in the pursuit of technological progress. Small Business Economics, 4, 1-14.

Cohen, W.M. and S. Klepper (1996). A reprise of size and R\&D. Economic Joumal, 106, 925-951.

Davis, S.J., J. Haltiwanger and S. Schuh (1996). Small business and job creation: Dissecting the myth and reassessing the facts. Small Business Economics, 8, 297-315.

Dosi, G. (1988). Sources, procedures and microeconomic effects of innovations. Jounal of Economic Literature, 26, 1120-1171.

EIM/ENSR (1997). The European Observatory: Fifth Annual Report. Zoetermeer: EIM Business and Policy Research.

Eliasson, G.E. (1995). Economic growth through competitive selection. Paper presented at 22 nd Annual E.A.R.I.E. Conference 3-6 September 1995, mimeo.

European Commission (2000). The European Observatory for SME: Sixth Report, submitted to the Enterprise Directorate General, Luxembourg: KPMG Consulting, EIM Business and Policy Research, and ENSR.

Eurostat (1994). Enterprises in Europe, third edition. Luxembourg.

Evans, D.S. and L.S. Leighton (1989). Some empirical aspects of entrepreneurship. Americam Econonic Review, 79, 519-535.

Foelster, S. (2000). Do entrepreneurs create jobs? Small Business Economlcs, 14(2), 137-148.

Freeman, C. and C. Perez (1988). Structural crises of adjustment: Business cycles and investment behavior. In G. Dosi, C. Freeman, R. Nelson, G. Silverberg and L. Soete (eds.), Technical Change and Economic Theory. London: Pinter Publishers.

Fritsch, M. (1997). New firms and regional employment change. Small Business Economics, 9, 437-448. 
Galbraith, J.K. (1967). The New Industrial State. London: Routledge.

Gartner, W.B. (1989). "Who is an entrepreneur?" Is the wrong question. Entrepreneurship Theory and Practice, 13, 47-68.

Glaeser, E.L., H.D. Kallal, J.A. Scheinkman and A. Shleifer (1992). Growth in cities. Joumal of Political Economy, 100, 1126-1152.

Grossman, G.M. and E. Helpman (1994). Endogenous innovation in the theory of growth. Joumal of Economic Perspectives, 8(1), 23-44.

Hart, M. and E. Harvey (1995). Job generation and new and small firms: Some evidence from the late 1980s. Small Business Economics, 7, 97-109.

Hébert, R.F. and A.N. Link (1982). The Entrepreneul. New York: Praeger.

Hébert, R.F. and A.N. Link (1989). In search of the meaning of entrepreneurship. Small Business Economics, 1, 39-49.

Holcombe, R.G. (1998). Entrepreneurship and economic growth. Quarterly Journal of Aurstrian Economics, 1(2), 45-62.

Holmes, T.J. and J.A. Schmitz $\mathrm{J}_{1}$. (1990). A theory of entrepreneurship and its application to the study of business transfers. Journal of Political Economy, 98, 265-294.

Howitt, P. and P. Aghion (1998). Capital accumulation and innovation as complementary factors in long-run growth. Joumal of Economic Growth, 3, 111-130.

Ilmakunnas, P. and V. Kanniainen (2001). Entrepreneurship, economic risks, and risk insurance in the welfare state: Results with OECD data 1978-93. German Economic Review, 2, 195-218.

Inman, R.P. (ed.) (1985). Managing the Service Economy. Cambridge, UK: Cambridge University Press.

Iyigun, M.F. and A.L. Owen (1998). Risk, entrepreneurship, and human capital accumulation. American Economic Review, Papers and Proceedings, 88, 454-457.

Tyigun, M.F. and A.L. Owen (1999). Entrepreneurs, professionals, and growth. Jounal of Economic Growth, 4, 213-232.

Jackson, L.F. (1984). Hierarchic demand and the Engle curve for variety. Review of Economics and Statistics, 66, 8-15.

Jensen, M.C. (1993). The modern industrial revolution, exit, and the failure of internal control systems. Journal of Finance, 68, 831-880.

Jovanovic, B. (1993). The diversification of production. Brookings Papers: Microeconomics, 1993, 197-235.

Kihlstrom, R.E. and J.J. Laflont (1979). A general equilibrium entrepreneurial theory of firm formation based on risk aversion. Journal of Political Economy, 87, 719-748.

Kirchhoff, B.A. (1994). Entrepreneurship and Dynamic Capitalism. Westport, CT: Praeger.

Kirchhoff, B.A. (1996). Self-employment and dynamic capitalism. Journal of Labor Research, 17, 627-643.

Kirzner, I.M. (1997). Entrepreneurial discovery and the competitive market process: An Austrian approach. Joul'nal of Economic Literatt'e, 35, 60-85.

Klodt, H. (1990). Industrial policy and repressed structural change in West Germany. Jahrbücher fïr Nationalökonomie und Statistik, 207, 25-35.

Krugman, P. (1991). Geography and Trade. Cambridge, MA: MIT Press.

Kuznets, S. (1971), Economic Growth of Nations, Total Output and Production Structure. Cambridge, MA: Harvard University Press/Belknapp Press.

Lever, M.H.C. and H.R. Nieuwenhuijsen (1999). The impact of competition on productivity in Dutch manufacturing. In D.B. Audretsch and A.R. Thurik (eds.), Innovation, Indistry Evolution and Employment. Cambridge, UK: Cambridge University Press, pp. 111-128.

Lloyd-Ellis, H. and D. Bernhardt (2000). Enterprise, inequality and economic development. Review of Economic Studies, 67, 147-168.

Loveman, G. and W. Sengenberger (1991). The re-emergence of small-scale production: An international comparison. Small Business Economics, 3, 1-37.

Lucas, R.E. (1978). On the size distribution of firms. BELL Journal of Economics, 9, 508-523.

Lucas, R.E. (1988). On the mechanics of economic development. Journal of Monetary Economics, $22,3-42$. 


\section{M.A. Carree and A.R. Thurik}

Lumpkin, G.T. and G.G. Dess (1996). Clarifying the entrepreneurial orientation construct and linking it to performance. Acadeny of Management Review, 21, 135-172.

McMillan, $J$. and C. Woodruff (2002). The central role of entrepreneurs in transition economies. Jonnal of Economic Perspectives, 16(3), 153-170.

Meredith, J. (1987). The strategic advantages of new manufacturing technologies for small firms. Strategic Management Jownal, 8, 249-258.

Nickell, S.J. (1996). Competition and corporate performance. Journal of Political Economy, 104, 724-746.

Nickell, S., P. Nicolitsas and N. Dryden (1997). What makes firms perform well? European Economic Review, 41, 783-796.

Nolan, P. (1995). China's Rise, Russia's Fall: Politics, Economics and Planning in the Transitionfrom Stalinism. New York: St Martin's Press.

OECD (1995). Competition Policy in OECD Countries, 1992-1993. Paris.

OECD (1998). Fostering Entrepreneurship. Paris.

Peng, B. (2000). Is entrepreneurship always good for growth? CRIEFF Discussion Paper 0024, University of St. Andrews.

Peretto, P.F. (1998). Technological change, market rivalry, and the evolution of the capitalist engine of growth. Jounal of Economic Growth, 3, 53-80.

Peretto, P.F. (1999a). Firm size, rivalry and the extent of the market in endogenous technological change. European Econonic Review, 43, 1747-1773.

Peretto, P.F. (1999b). Industrial development, technological change, and longwrun growth. Journal of Development Economics, 59, 389-417.

Phillips, B.D. (1985). The effect of industry deregulation on the small business sector. Business Economics, 20, 28-37.

Piore, M.J. and C.F. Sabel (1984). The Second Industrial Divide: Possibilities for Prosperity. New York: Basic Books.

Porter; M.E. (1990). The Competitive Advantage of Nations. New York: Free Press.

Prusa, T.J. and J.A. Schmitz Jr. (1991). Are new firms an important source of innovation'? Evidence from the software industry, Economics Letters, 35, 339-342

Reynolds, P.D. (1999). Creative destruction: Source or symptom of econonic growth'? In Z.J. Acs, B. Carlsson and C. Karlsson (eds.), Eutrepreneurship, Small and Medium-Sized Enterprises and the Macroeconomy. Cambridge, UK: Cambridge University Press, pp. 97-136.

Reynolds, P.D., S.M. Camp, W.D. Bygrave, E. Autio and M. Hay (2001). Glohal Entrepreneurship Monitor - 2001 Executive Report [online]. Babson College, IBM, Kauffman Center for Entrepreneurial Leadership and London Business School. Available: htlp://www.gemconsortium.org, accessed December 2002.

Reynolds, P.D. (1999). Creative destruction: Source or symptom of economic growth'? In Zoltan J. Acs, Bo Carlsson and Charlie Karlsson (eds.), Entrepreneurship, Small and Medium-sized Enterprises and the Macroeconomy. Cambridge: Cambridge University Press, pp. 97-136.

Robbins, D.K., L.J. Pantuosco, D.F. Parker and B.K. Fuller (2000). An empirical assessment of the contribution of small business employment to U.S. state economic performance. Small Business Economics, 15, 293-302.

Romer, P.M. (1986). Increasing return and long-run growth. Journal of Political Economy, 94, $1002-1037$.

Romer, P.M. (1990). Endogenous technological change. Journal of Political Economy, 98, 71-101.

Romer, P.M. (1994). The origins of endogenous growth. Joumal of Economic Perspectives, 8, 3-22.

Rothwell, R. (1983). Innovation and firm size: A case for dynamic complementarity; or, is small really so beautiful? Joumal of General Management, 8, 5-25.

Rothwell, R. (1984). The role of small firms in the emergence of new technologies. OMEGA, $12,19-29$.

Schaffner, J.A. (1993). Rising incomes and the shift from self-employment to firm-based production. Economies Letter's, 41, 435-440.

Scherer, F.M. and D. Ross (1990). Industrial Market Structure and Economic Performance. Boston, MA: Houghton Mifflin Company. 
Schiller, B.R. and P.E. Crewson (1997), Entrepreneurial origins: A longitudinal inquiry. Economic Inquiry, 35, 523-531.

Schmitz, Jr. J.A. (1989). Imitation, entrepreneurship, and long-run growth. Joumal of Political Economy, 97, 721 739.

Schultz, T.P. (1990). Women's changing participation in the labor force: A world perspective. Economic Development and Cultural Change, 38, 457-488.

Schumpeter, J.A. (1934). The Theory of Economic Development. Cambridge, MA: Harvard University Press.

Schumpeter, J.A. (1950). Capitalism, Socialism and Democracy. New York: Harper and Row.

Shane, S. (2000). Prior knowledge and the discovery of entrepreneurial opportunities. Organization Science, 11, 448-469.

Solow, R.M. (1970). Growth Theory: An Exposition. Oxford, UK: Oxford University Press.

Sternberg, R. (1996). Technology policies and the growth of regions. Small Business Economics, 8, 75-86.

Storey, D.J. and B.S. Tether (1998). Public policy measures to support new technology-based firms in the European Union. Research Policy, 26, 1037-1057.

Sutton, J. (1997). Gibrat's legacy. Jounal of Economic Literature, 35, 40-59.

Thurik, A.R. (1996). Small firms, entrepreneurship and economic growth. In P.H. Admiraal (ed.), Small Business in the Modern Economy. De Vries Lectures in Economics, Oxford, UK: Blackwell Publishers.

Thurik, A.R. (1999). Entrepreneurship, industrial transformation and growth. In G.D. Libecap (ed.), The Sources of Entreprenetrial Activity, Vol. 11, Advances in the Study of Entrepreneurship, Innovation, and Economic Growth, pp. 29-65. Stamford, CT; JAI Press.

Wennekers, A.R.M. and A.R. Thurik (1999). Linking entrepreneurship and economic growth. Small Business Economics, 13, 27-55.

Wennekers, S., L.H. Uhlaner and R. Thurik (2002). Entrepreneurship and its conditions: A macro perspective, Intemational Jounal of Entreprenewrship Education, 1, forthcoming.

Yamada, G. (1996). Urban informal employment and self-employment it developing countries: Theory and evidence. Econonic Development and Cultural Change, 44, 289-314.

Yu, T.F. (1998). Adaptive entrepreneurship and the economic development of Hong Kong. World Development, 26, 897-911. 